Supplement of

\title{
Development of an instrument for direct ozone production rate measurements: measurement reliability and current limitations
}

Sofia Sklaveniti et al.

Correspondence to: Sébastien Dusanter (sebastien.dusanter@imt-lille-douai.fr)

The copyright of individual parts of the supplement might differ from the CC BY 4.0 License. 


\section{Supplementary material}

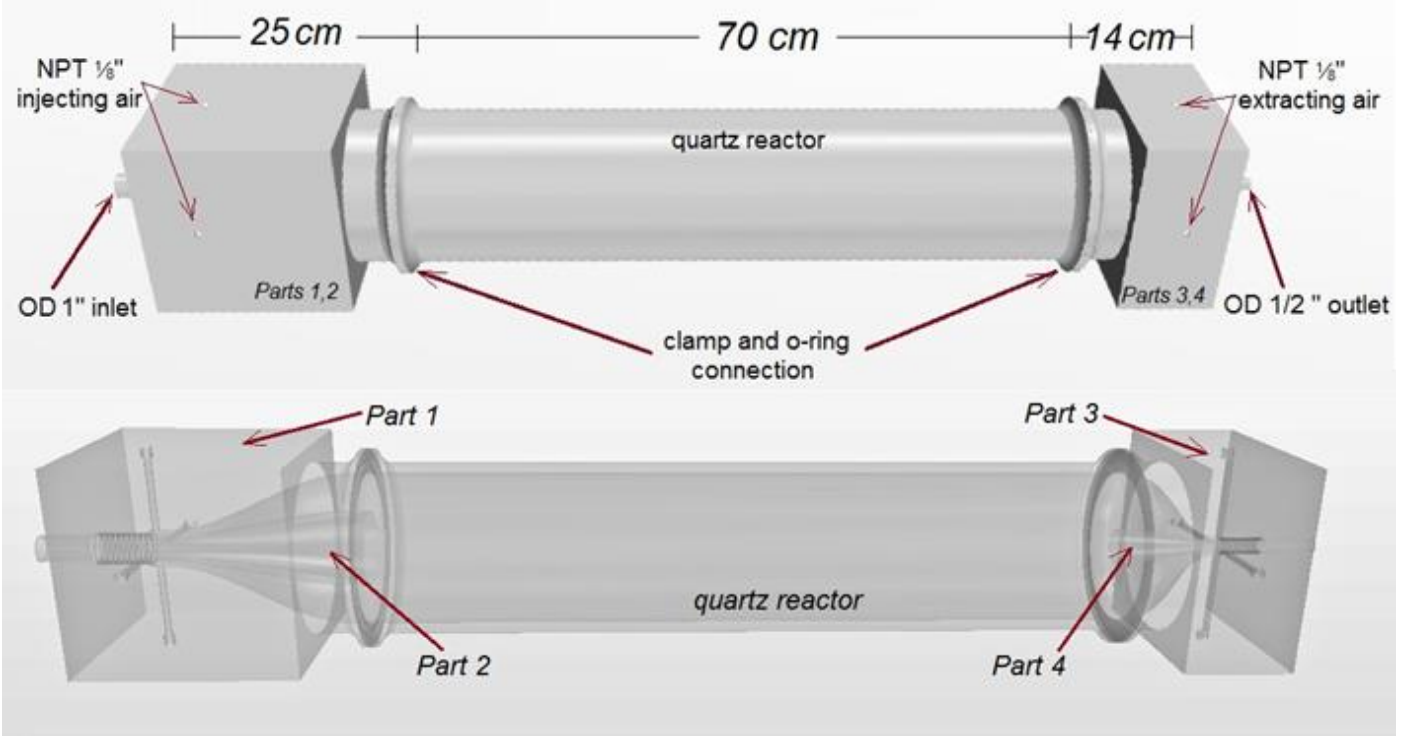

4 Figure S1. Design of the OPR flow tubes

\section{S2. Assessment of potential measurement biases}

Table S1. Average and peak values of $\mathrm{O}_{3}, \mathrm{NO}_{\mathrm{x}}$, total VOCs, $\mathrm{OH}$ reactivity, $\mathrm{J}\left(\mathrm{NO}_{2}\right)$ and $\mathrm{J}\left(\mathrm{O}^{1} \mathrm{D}\right)$, as well as timing of the peaks, for the selected days of the MCMA-2006 and the CalNex-2010 field campaigns.

\begin{tabular}{|c|c|c|c|c|c|}
\hline \multirow[b]{2}{*}{ Species } & & \multicolumn{2}{|c|}{ МСMА-2006 } & \multicolumn{2}{|c|}{ CalNex-2010 } \\
\hline & & $\begin{array}{c}19 \text { March 2006 } \\
9: 00-18: 00\end{array}$ & $\begin{array}{c}21 \text { March 2006 } \\
8: 30-18: 30\end{array}$ & $\begin{array}{c}\text { 30 May 2010 } \\
8: 00-18: 30\end{array}$ & $\begin{array}{c}\text { 08 June 2010 } \\
8: 00-18: 30\end{array}$ \\
\hline \multirow{3}{*}{$\begin{array}{c}\mathbf{O}_{3} \\
(\mathbf{p p b v})\end{array}$} & average & 40.9 & 73 & 69.8 & 35.0 \\
\hline & $\max$ & 47.9 & 119.7 & 108.7 & 46.4 \\
\hline & peak timing & $11: 10$ & $16: 50$ & $13: 45$ & $15: 30$ \\
\hline \multirow{3}{*}{$\begin{array}{c}\mathrm{NO}_{2} \\
(\mathbf{p p b v})\end{array}$} & average & 10.8 & 24.8 & 8.0 & 13.2 \\
\hline & $\max$ & 36.3 & 69.9 & 14.3 & 20.3 \\
\hline & peak timing & 09:00 & 09:10 & $11: 45$ & $12: 45$ \\
\hline \multirow{3}{*}{$\begin{array}{c}\text { NO } \\
(\text { ppbv) }\end{array}$} & average & 5.1 & 10.0 & 2.1 & 5.2 \\
\hline & $\max$ & 18.8 & 61.5 & 5.1 & 13.2 \\
\hline & peak timing & 09:00 & $8: 30$ & $08: 15$ & $12: 45$ \\
\hline \multirow{3}{*}{$\begin{array}{c}\text { Total VOCs } \\
\text { (ppbv) }\end{array}$} & average & 56.4 & 165.0 & 43.2 & 47.1 \\
\hline & $\max$ & 148.5 & 331.8 & 49.6 & 68.0 \\
\hline & peak timing & 09:00 & 08:30 & $11: 30$ & $13: 00$ \\
\hline \multirow{3}{*}{$\begin{array}{c}\mathrm{OH} \text { reactivity } \\
\left(\mathrm{s}^{-1}\right)\end{array}$} & average & 12.9 & 35.8 & 14.6 & 14.9 \\
\hline & $\max$ & 35.7 & 86.3 & 17.8 & 22.3 \\
\hline & peak timing & 09:00 & 08:30 & $11: 30$ & 13:00 \\
\hline \multirow{3}{*}{$\begin{array}{l}\mathbf{J}\left(\mathbf{N O}_{2}\right) \\
\left(\mathbf{s}^{-1}\right)\end{array}$} & average & $7.2 \times 10^{-3}$ & $5.2 \times 10^{-3}$ & $6.3 \times 10^{-3}$ & $5.6 \times 10^{-3}$ \\
\hline & $\max$ & $9.8 \times 10^{-3}$ & $9.2 \times 10^{-3}$ & $7.8 \times 10^{-3}$ & $8.4 \times 10^{-3}$ \\
\hline & peak timing & $12: 40$ & $12: 40$ & $13: 15$ & $11: 15$ \\
\hline \multirow{3}{*}{$\begin{array}{c}\mathbf{J}\left(\mathbf{O}^{1} \mathbf{D}\right) \\
\left(\mathbf{s}^{-1}\right)\end{array}$} & average & $2.7 \times 10^{-5}$ & $1.9 \times 10^{-5}$ & $1.6 \times 10^{-5}$ & $1.6 \times 10^{-5}$ \\
\hline & $\max$ & $4.8 \times 10^{-5}$ & $4.3 \times 10^{-5}$ & $2.7 \times 10^{-5}$ & $2.9 \times 10^{-5}$ \\
\hline & peak timing & $12: 30$ & $12: 40$ & $12: 45$ & $12: 30$ \\
\hline
\end{tabular}



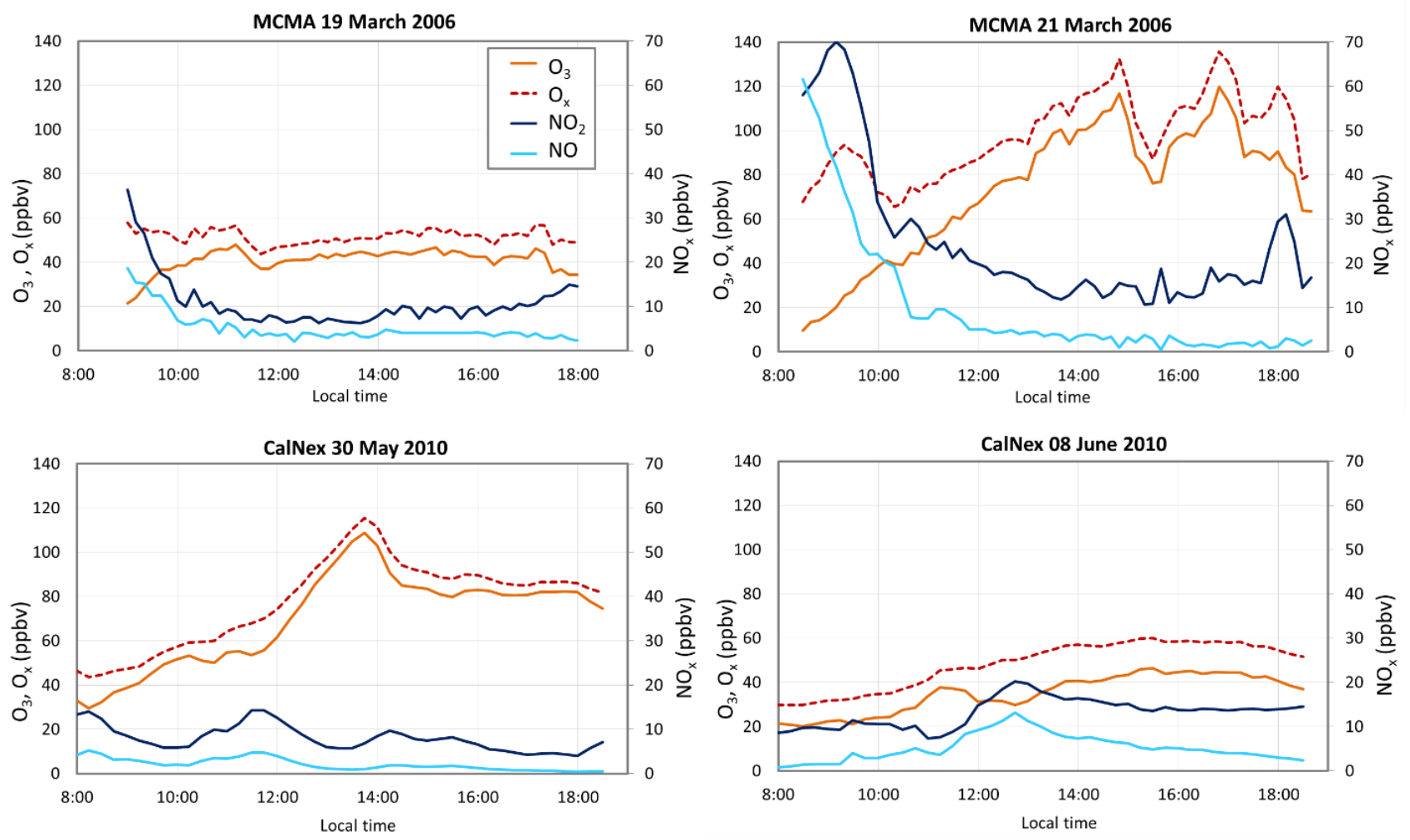

Figure S2. Ambient mixing ratios of $\mathrm{O}_{3}, \mathrm{NO}_{\mathrm{x}}$ and $\mathrm{O}_{\mathrm{x}}$ for the selected days of the MCMA-2006 (top) and

3 CalNex-2010 (bottom) campaigns.

\section{$5 \quad$ S2.1 Quantification of photolysis frequencies under the UV filter}

6 The absorption coefficient $\alpha$ of the Ultem film is linked to its light transmission:

$7 \quad I=I_{0} e^{-a x}$

8 where $\mathrm{I}$ and $\mathrm{I}_{\mathrm{o}}$ are the transmitted and incident actinic fluxes, respectively, and $\mathrm{x}$ is the film thickness

9 (0.25 mm) (Philipp et al., 1989). The actinic flux $\mathrm{I}_{\mathrm{o}}(\lambda)$ was calculated by the Tropospheric Ultraviolet-

10 Visible model (TUV version 5.2) (Madronich and Flocke, 1999) for the selected days of the MCMA-

112006 campaign and the transmission of the Ultem film was then calculated for each wavelength from

12 Eq. (2), as shown in Fig. S3. J-values for $\mathrm{NO}_{2}, \mathrm{O}\left({ }^{1} \mathrm{D}\right)$ and $\mathrm{NO}_{3}$ were then calculated for clear sky

13 conditions (ambient J-values) and for the UV filter (reference J-values) as:

$14 \quad$ Jvalue $=\int_{\lambda_{1}}^{\lambda_{2}} I(\lambda) \sigma(\lambda) \varphi(\lambda) d \lambda$ 
1 using the incident and transmitted actinic fluxes, respectively, the absorption cross section $\sigma(\lambda)$ and

2 the quantum yield $\varphi(\lambda)$ for each molecule. For $\mathrm{NO}_{3}$, both photolysis channels (producing $\mathrm{NO}+\mathrm{O}_{2}$ and

$3 \quad \mathrm{NO}_{2}+\mathrm{O}$ ) where examined separately.

4 The ratio between reference and ambient $\mathrm{J}$-values provides a scaling transmission factor for each

5 species $\left(\mathrm{NO}_{2}, \mathrm{O}_{3} \rightarrow \mathrm{O}\left({ }^{1} \mathrm{D}\right)\right.$ and $\left.\mathrm{NO}_{3}\right)$. Chemical species photolyzed at wavelengths shorter than $400 \mathrm{~nm}$

6 were scaled using the scaling factor derived from $\mathrm{J}\left(\mathrm{O}^{1} \mathrm{D}\right)$. Species photolyzed at wavelengths up to

$7 \quad 450 \mathrm{~nm}$ (glyoxal, methylglyoxal, other $\alpha$-carbonyl aldehydes and unsaturated dicarbonyls) were

8 scaled using the scaling factor derived from $\mathrm{J}\left(\mathrm{NO}_{2}\right)$. Both channels of $\mathrm{NO}_{3}$ photolysis lead to similar

9 scaling factors with a difference $<2 \%$, and an average was used. The scaling factor of $\mathrm{J}\left(\mathrm{NO}_{3}\right)$ was

10 used for the photolysis of $\mathrm{O}_{3}$ leading to $\mathrm{O}\left({ }^{3} \mathrm{P}\right)$.

11

12

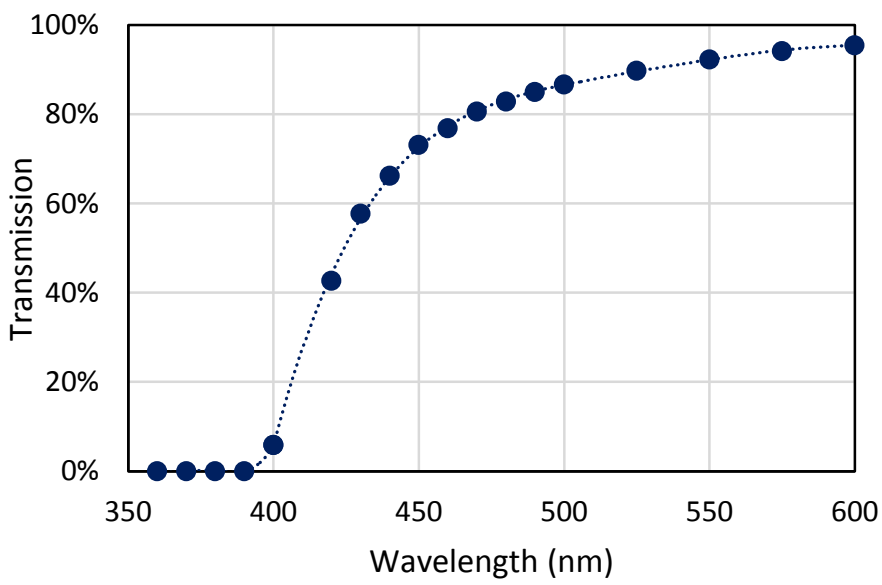

Figure S3. Transmission of light through the UV filter, $0.25 \mathrm{~mm}$ thick, as calculated by the absorption coefficient of polyetherimide (Ultem film). 
$1 \quad$ S2.2 Modeling of the chemistry in the flow tubes

2 Table S2. Compounds constrained in the model for $\mathrm{P}\left(\mathrm{O}_{3}\right)_{\mathrm{amb}}$

\begin{tabular}{|c|c|c|c|}
\hline Species & Definition & Species & Definition \\
\hline $\mathrm{O} 3$ & Ozone & $\mathrm{HC} 3$ & $\begin{array}{l}\text { Alkanes, alcohols, esters and alkynes with } \mathrm{OH} \text { rate } \\
\text { constant }(298 \mathrm{~K}, 1 \mathrm{~atm}) \text { less than } 3.4 \times 10^{-12} \mathrm{~cm}^{3} \mathrm{~s}^{-1}\end{array}$ \\
\hline $\mathrm{SO} 2$ & Sulfur dioxide & HC5 & $\begin{array}{l}\text { Alkanes, alcohols, esters and alkynes with } \mathrm{OH} \text { rate } \\
\text { constant }(298 \mathrm{~K}, 1 \mathrm{~atm}) \text { between } 3.4 \times 10^{-12} \mathrm{~cm}^{3} \mathrm{~s}^{-1} \text { and } \\
6.8 \times 10^{-12} \mathrm{~cm}^{3} \mathrm{~s}^{-1}\end{array}$ \\
\hline $\mathrm{CO}$ & Carbon monoxide & $\mathrm{HC} 8$ & $\begin{array}{l}\text { Alkanes, alcohols, esters and alkynes with } \mathrm{OH} \text { rate } \\
\text { constant }(298 \mathrm{~K}, 1 \mathrm{~atm}) \text { greater than } 6.8 \times 10^{-12} \mathrm{~cm}^{3} \mathrm{~s}^{-1}\end{array}$ \\
\hline $\mathrm{H} 2$ & Hydrogen & OLT & Terminal alkenes \\
\hline HONO & Nitrous acid & OLI & Internal alkenes \\
\hline NO & Nitric oxide & TOL & Toluene and less reactive aromatics \\
\hline $\mathrm{NO} 2$ & Nitrogen dioxide & XYL & Xylene and more reactive aromatics \\
\hline $\mathrm{CH} 4$ & Methane & $\mathrm{HCHO}$ & Formaldehyde \\
\hline ETH & Ethane & ALD & Acetaldehyde and higher aldehydes \\
\hline ETE & Ehtene & API & $\alpha$-pinene and other cyclic terpenes with one double bond \\
\hline ISO & Isoprene & DIEN & Butadiene and other anthropogenic dienes \\
\hline GLY & Glyoxal & KET & Ketones \\
\hline
\end{tabular}

3

5 Table S3. Photolytic reactions included in the model using their RACM notation. J-values scaling factors for the 6 Reference flow tube. For a detailed explanation of the RACM notation see Stockwell et al. (1997).

7

\begin{tabular}{|c|c|c|c|c|c|c|c|}
\hline Photolytic reaction & $\begin{array}{l}\text { RACM } \\
\text { symbol } \\
\end{array}$ & $\begin{array}{l}\text { Scaling } \\
\text { factor }\end{array}$ & $\begin{array}{l}\text { Value of } \\
\text { sc. factor }\end{array}$ & Photolytic reaction & $\begin{array}{l}\text { RACM } \\
\text { symbol } \\
\end{array}$ & $\begin{array}{l}\text { Scaling } \\
\text { factor }\end{array}$ & $\begin{array}{l}\text { Value of } \\
\text { sc. factor }\end{array}$ \\
\hline $\mathrm{NO}_{2} \rightarrow \mathrm{NO}+\mathrm{O}\left({ }^{3} \mathrm{P}\right)$ & $\mathrm{JNO} 2$ & $\mathrm{JNO} 2$ & 0.02 & $\mathrm{CH}_{3} \mathrm{OOH} \rightarrow \mathrm{HO}_{2}+\mathrm{OH}+\mathrm{HCHO}$ & JOP1 & JO1D & 0 \\
\hline $\mathrm{O}_{3} \rightarrow \mathrm{O}\left({ }^{1} \mathrm{D}\right)+\mathrm{O}_{2}$ & JO1D & JO1D & 0 & $\mathrm{OP}_{2} \rightarrow \mathrm{HO}_{2}+\mathrm{OH}+\mathrm{ALD}$ & JOP2 & JO1D & 0 \\
\hline $\mathrm{O}_{3} \rightarrow \mathrm{O}\left({ }^{3} \mathrm{P}\right)+\mathrm{O}_{2}$ & JO3P & $\mathrm{JNO} 3$ & 0.82 & $\mathrm{PAA} \rightarrow \mathrm{CH}_{3} \mathrm{O}_{2}+\mathrm{OH}$ & JPAA & JO1D & 0 \\
\hline $\mathrm{HONO} \rightarrow \mathrm{HO}+\mathrm{NO}$ & JHONO & JO1D & 0 & $\mathrm{KET} \rightarrow \mathrm{ETHP}+\mathrm{ACO} 3$ & JKET & JO1D & 0 \\
\hline $\mathrm{HNO}_{3} \rightarrow \mathrm{OH}+\mathrm{NO}_{2}$ & JHNO3 & JO1D & 0 & $\mathrm{GLY} \rightarrow \mathrm{HCHO}+\mathrm{CO}$ & JGLY1 & $\mathrm{JNO} 2$ & 0.02 \\
\hline $\begin{array}{l}\mathrm{HO}_{2} \mathrm{NO}_{2} \rightarrow 0.65 \mathrm{HO}_{2}+ \\
0.65 \mathrm{NO}_{2}+0.35 \mathrm{OH}+0.35 \mathrm{NO}_{3}\end{array}$ & $\mathrm{JHO} 2 \mathrm{NO} 2$ & JO1D & 0 & $\mathrm{GLY} \rightarrow \mathrm{CO}+\mathrm{H}_{2}$ & JGLY2 & $\mathrm{JNO} 2$ & 0.02 \\
\hline $\mathrm{NO}_{3} \rightarrow \mathrm{NO}+\mathrm{O}_{2}$ & JNO3_NO & JNO3 & 0.82 & $\mathrm{GLY} \rightarrow \mathrm{HO}_{2}+\mathrm{HO}_{2}$ & JGLY3 & $\mathrm{JNO} 2$ & 0.02 \\
\hline $\mathrm{NO}_{3} \rightarrow \mathrm{NO}_{2}+\mathrm{O}\left({ }^{3} \mathrm{P}\right)$ & JNO3_NO2 & JNO3 & 0.82 & $\mathrm{MGLY} \rightarrow \mathrm{HO}_{2}+\mathrm{ACO}+\mathrm{CO}$ & JMGLY & $\mathrm{JNO} 2$ & 0.02 \\
\hline $\mathrm{H}_{2} \mathrm{O}_{2} \rightarrow \mathrm{OH}+\mathrm{OH}$ & $\mathrm{JH} 2 \mathrm{O} 2$ & JO1D & 0 & $\mathrm{DCB} \rightarrow \mathrm{TCO} 3+\mathrm{HO}_{2}$ & JDCB & $\mathrm{JNO} 2$ & 0.02 \\
\hline $\mathrm{HCHO} \rightarrow \mathrm{HO}_{2}+\mathrm{HO}_{2}+\mathrm{CO}$ & JHCHO_CO & JO1D & 0 & $\mathrm{ONIT} \rightarrow \mathrm{HO}_{2}+\mathrm{NO}_{2}+0.2 \mathrm{ALD}+0.8 \mathrm{KET}$ & JONIT & JO1D & 0 \\
\hline $\mathrm{HCHO} \rightarrow \mathrm{CO}+\mathrm{H}_{2}$ & JHCHO_H2 & JO1D & 0 & $\mathrm{MACR} \rightarrow \mathrm{CO}+\mathrm{HO}_{2}+\mathrm{ACO} 3+\mathrm{HCHO}$ & JMACR & JO1D & 0 \\
\hline $\mathrm{ALD} \rightarrow \mathrm{CH}_{3} \mathrm{O}_{2}+\mathrm{HO}_{2}+\mathrm{CO}$ & JALD & JO1D & 0 & $\mathrm{HKET} \rightarrow \mathrm{HO}_{2}+\mathrm{ACO} 3+\mathrm{HCHO}$ & JHKET & JO1D & 0 \\
\hline
\end{tabular}


1 Table S4. Peroxy radical surrogates used for $\mathrm{p}\left(\mathrm{O}_{3}\right)$ calculations, and alkenes and organics used for $1\left(\mathrm{O}_{3}\right)$ 2 calculations. Peroxy radical outputs from the ambient atmospheric modeling were also used as model constraints 3 for the flow tubes modeling.

\begin{tabular}{|c|c|c|}
\hline & Species & Definition \\
\hline \multirow{19}{*}{$\begin{array}{l}\text { Peroxy radicals used } \\
\text { for } \mathrm{p}\left(\mathrm{O}_{3}\right) \text { calculation }\end{array}$} & $\mathrm{HO} 2$ & Hydroperoxy radical \\
\hline & $\mathrm{CH} 3 \mathrm{O} 2$ & Methyl peroxy radical \\
\hline & ETHP & Peroxy radical formed from ETH \\
\hline & HC3P & Peroxy radical formed from $\mathrm{HC} 3$ \\
\hline & HC5P & Peroxy radical formed from $\mathrm{HC} 5$ \\
\hline & $\mathrm{HC} 8 \mathrm{P}$ & Peroxy radical formed from $\mathrm{HC} 8$ \\
\hline & ETEP & Peroxy radical formed from ETE \\
\hline & OLTP & Peroxy radical formed from OLT \\
\hline & OLIP & Peroxy radical formed from OLI \\
\hline & ISOP & Peroxy radical formed from ISO and DIEN \\
\hline & APIP & Peroxy radical formed from API \\
\hline & LIMP & Peroxy radical formed from LIM \\
\hline & TOLP & Peroxy radical formed from TOL \\
\hline & XYLP & Peroxy radical formed from XYL \\
\hline & CSLP & Peroxy radical formed from CSL \\
\hline & $\mathrm{ACO} 3$ & Acetyl peroxy and higher saturated acyl peroxy radicals \\
\hline & TCO3 & Unsaturated acyl peroxy radicals \\
\hline & KETP & Peroxy radicals formed from KET \\
\hline & $\mathrm{XO} 2$ & Accounts for additional $\mathrm{NO}$ to $\mathrm{NO}_{2}$ conversions \\
\hline \multirow{10}{*}{$\begin{array}{l}\text { Alkenes + Organics used } \\
\text { for } \mathrm{l}\left(\mathrm{O}_{3}\right) \text { calculation }\end{array}$} & ETE & Ethene \\
\hline & OLT & Terminal alkenes \\
\hline & OLI & Internal alkenes \\
\hline & DIEN & Butadiene and other anthropogenic dienes \\
\hline & ISO & Isoprene \\
\hline & API & $\alpha$-pinene and other cyclic terpenes with one double bond \\
\hline & LIM & d-limonene and other cyclic diene-terpenes \\
\hline & MACR & Methacrolein and other unsaturated monoaldehydes \\
\hline & DCB & Unsaturated dicarbonyls \\
\hline & TPAN & Unsaturated PANs \\
\hline
\end{tabular}

Table S5. Secondary compounds constrained in the model.

\begin{tabular}{cl}
\hline Species & Definition \\
\hline N2O5 & Dinitrogen pentoxide \\
H2O2 & Hydrogen peroxide \\
CH3OOH & Methyl hydrogen peroxide \\
OP2 & Higher organic peroxides \\
MGLY & Methylglyoxal and other $\alpha$-carbonyl aldehydes \\
MACR & Methacrolein and other unsaturated monoaldehydes \\
UDD & Unsaturated dihydroxy dicarbonyl \\
HKET & Hydroxy ketone \\
DCB & Unsaturated dicarbonyls \\
ONIT & Organic nitrate \\
PAN & Peroxyacetyl nitrate and higher saturated PANs \\
TPAN & Unsaturated PANs \\
PAA & Peroxyacetic acid and higher analogs \\
ORA1 & Formic acid \\
ORA2 & Acetic acid and higher acids \\
HNO3 & Nitric acid \\
\hline
\end{tabular}



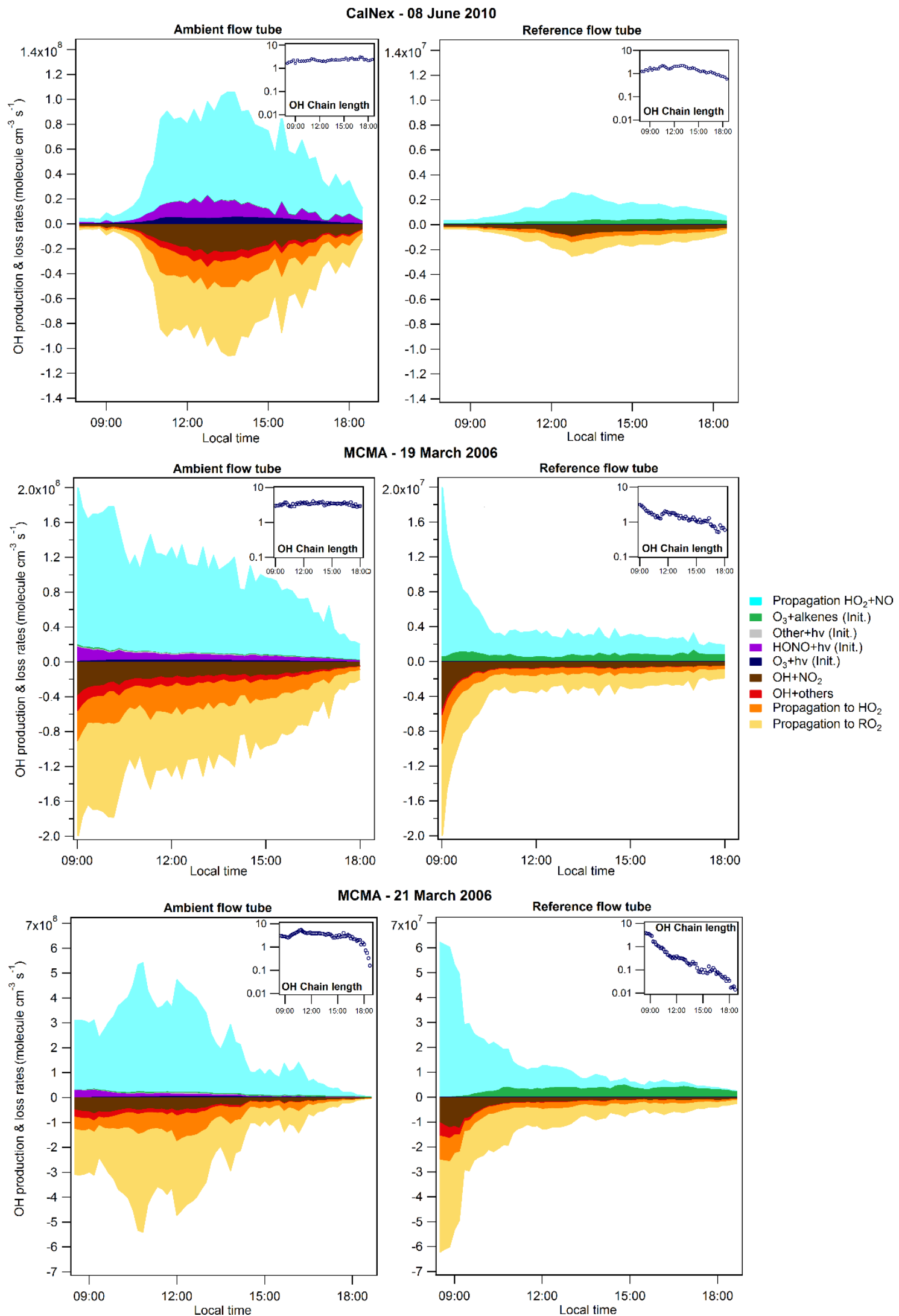

Figure S4. OH radical budgets for 08 May 2010 of CalNex-2010 (top), 19 March 2006 of MCMA-2006 (middle) and 21 March 2006 of MCMA-2006 (bottom). Radical budgets modeled for the ambient (left) and the reference (right) flow tubes. The $\mathrm{OH}$ chain length is also presented in an insert for each day and each flow tube.

5 The note (Init.) in the legend indicates initiation reactions. 

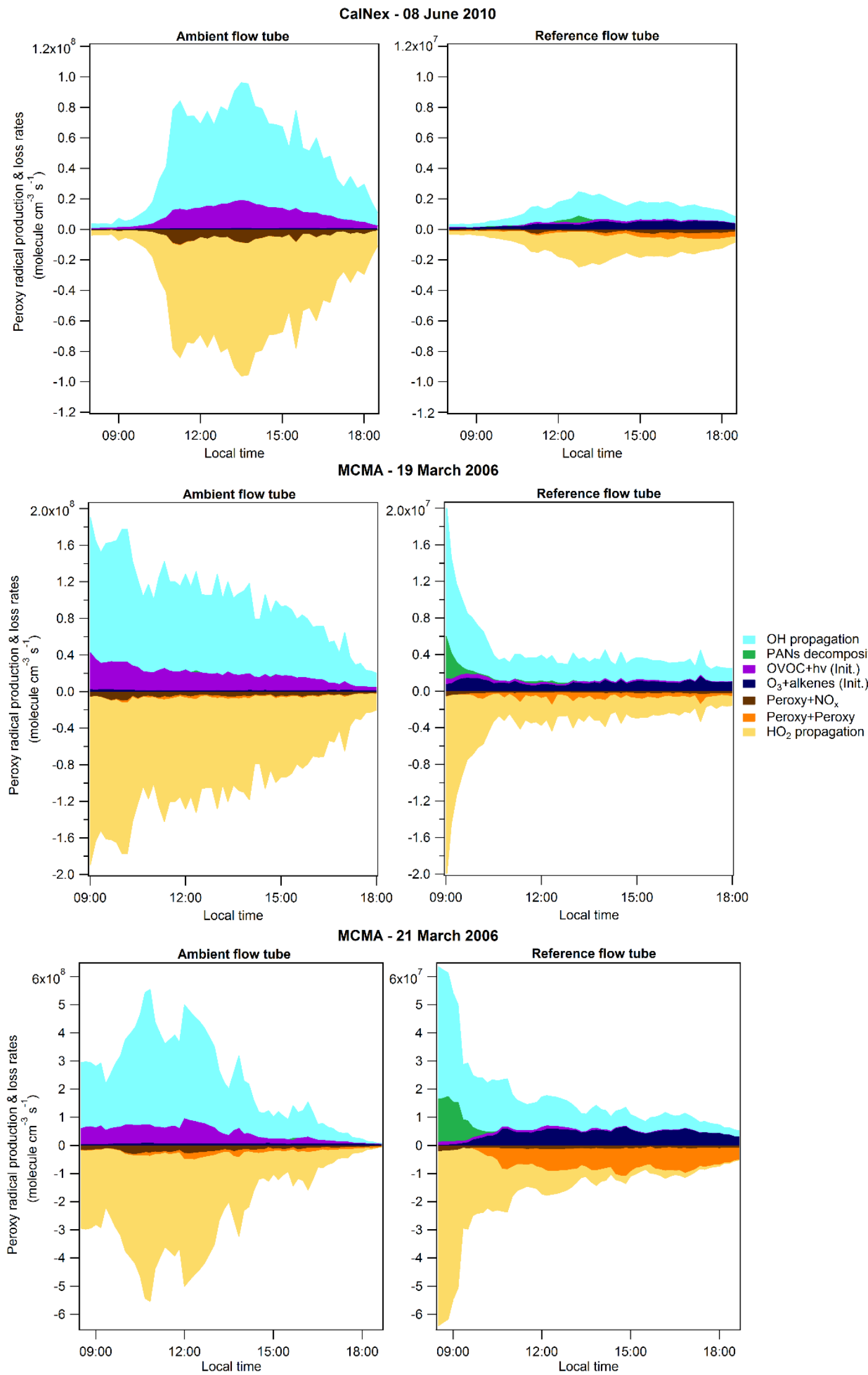

Figure S5. Total peroxy radical budgets for 8 May 2010 of CalNex-2010 (top), 19 March 2006 of MCMA2006 (middle) and 21 March 2006 of MCMA-2006 (bottom). Radical budgets modeled for the ambient (left) and the reference (right) flow tubes. The note (Init.) in the legend indicates initiation reactions. 
CalNex - 30 May 2010
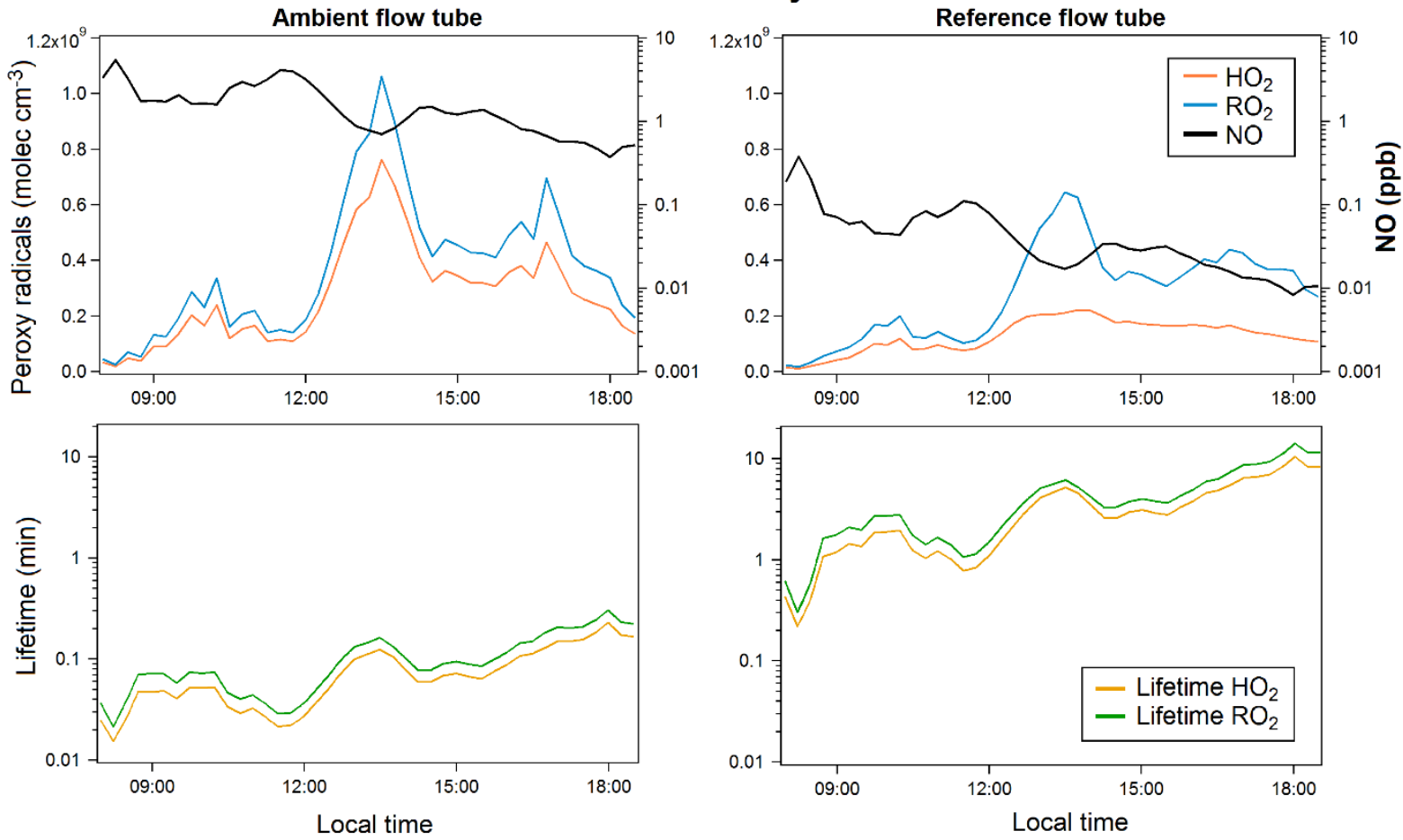

2 Figure S6. Peroxy radical concentrations, $\mathrm{NO}$ mixing ratios and lifetimes of $\mathrm{HO}_{2}$ and $\mathrm{RO}_{2}$ radicals in the 3 ambient (left) and reference (right) flow tubes during 30 May 2010 of the CalNex-2010 campaign.
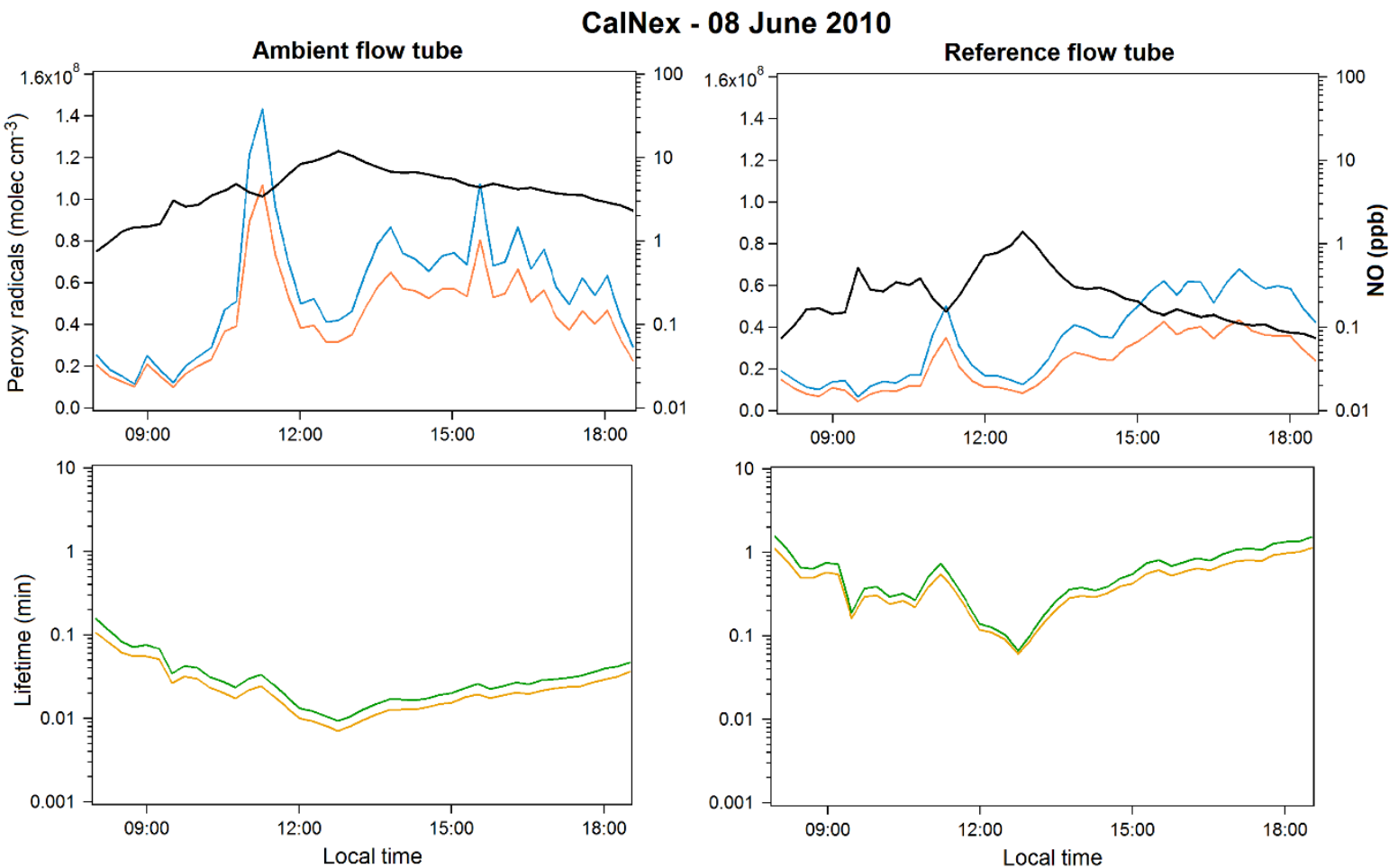

Figure S7. Peroxy radical concentrations, NO mixing ratios and lifetimes of $\mathrm{HO}_{2}$ and $\mathrm{RO}_{2}$ radicals in the ambient (left) and reference (right) flow tubes during 08 June 2010 of CalNex-2010. 

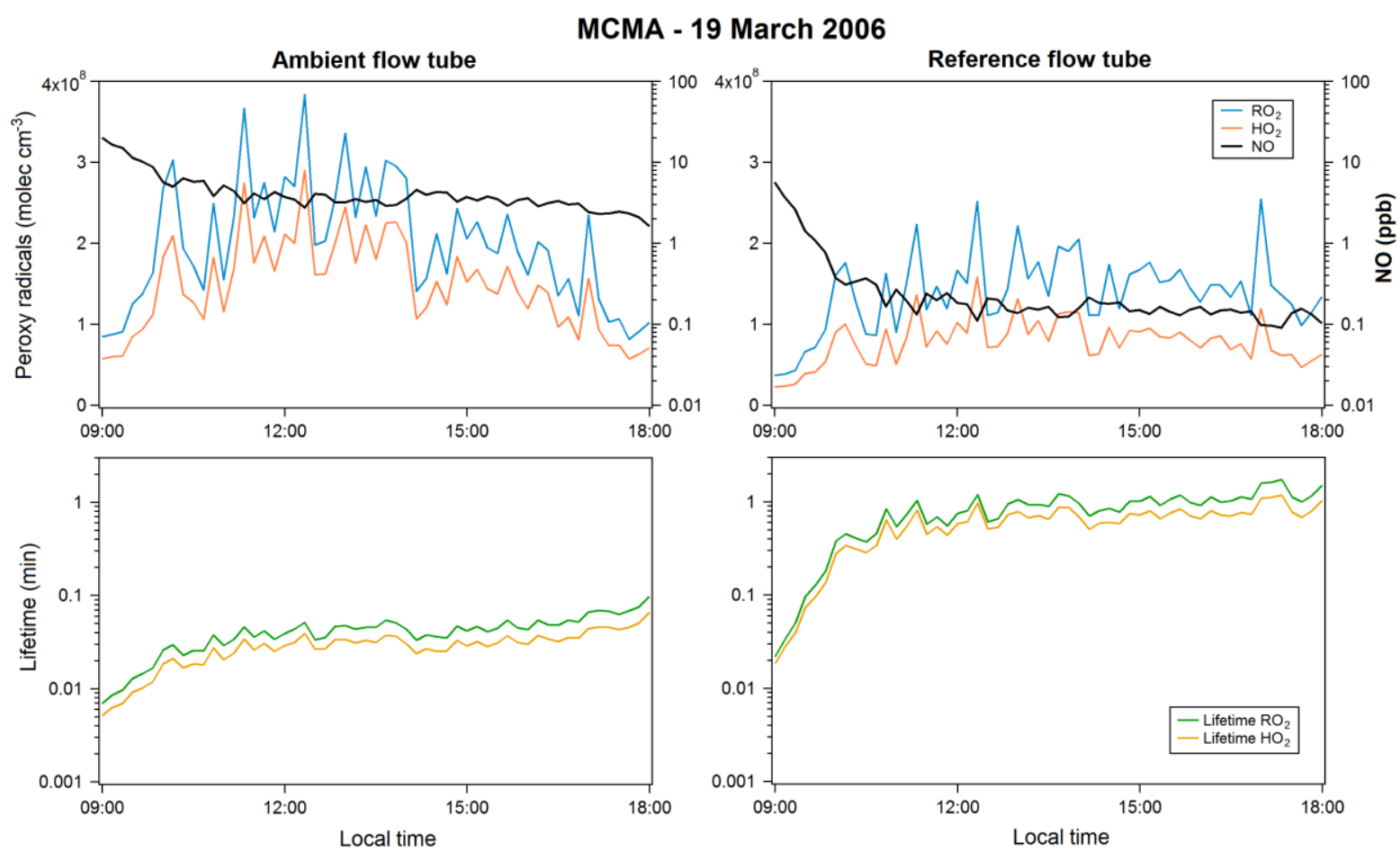

Figure S8. Peroxy radical concentrations, $\mathrm{NO}$ mixing ratios and lifetimes of $\mathrm{HO}_{2}$ and $\mathrm{RO}_{2}$ radicals in the ambient (left) and reference (right) flow tubes during 19 March 2006 of MCMA-2006.
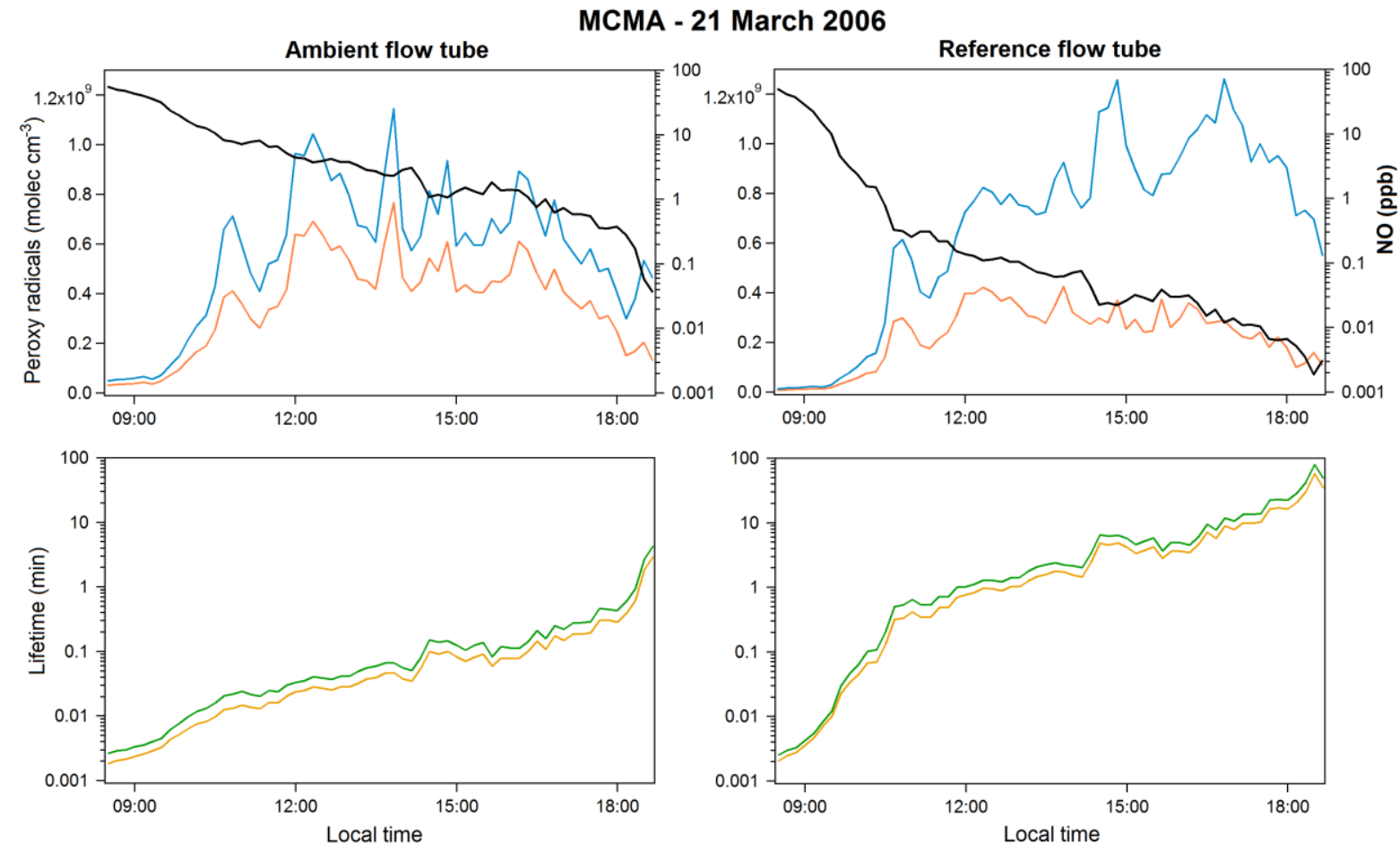

Figure S9. Peroxy radical concentrations, $\mathrm{NO}$ mixing ratios and lifetimes of $\mathrm{HO}_{2}$ and $\mathrm{RO}_{2}$ radicals in the ambient (left) and reference (right) flow tubes during 21 March 2006 of MCMA-2006. 

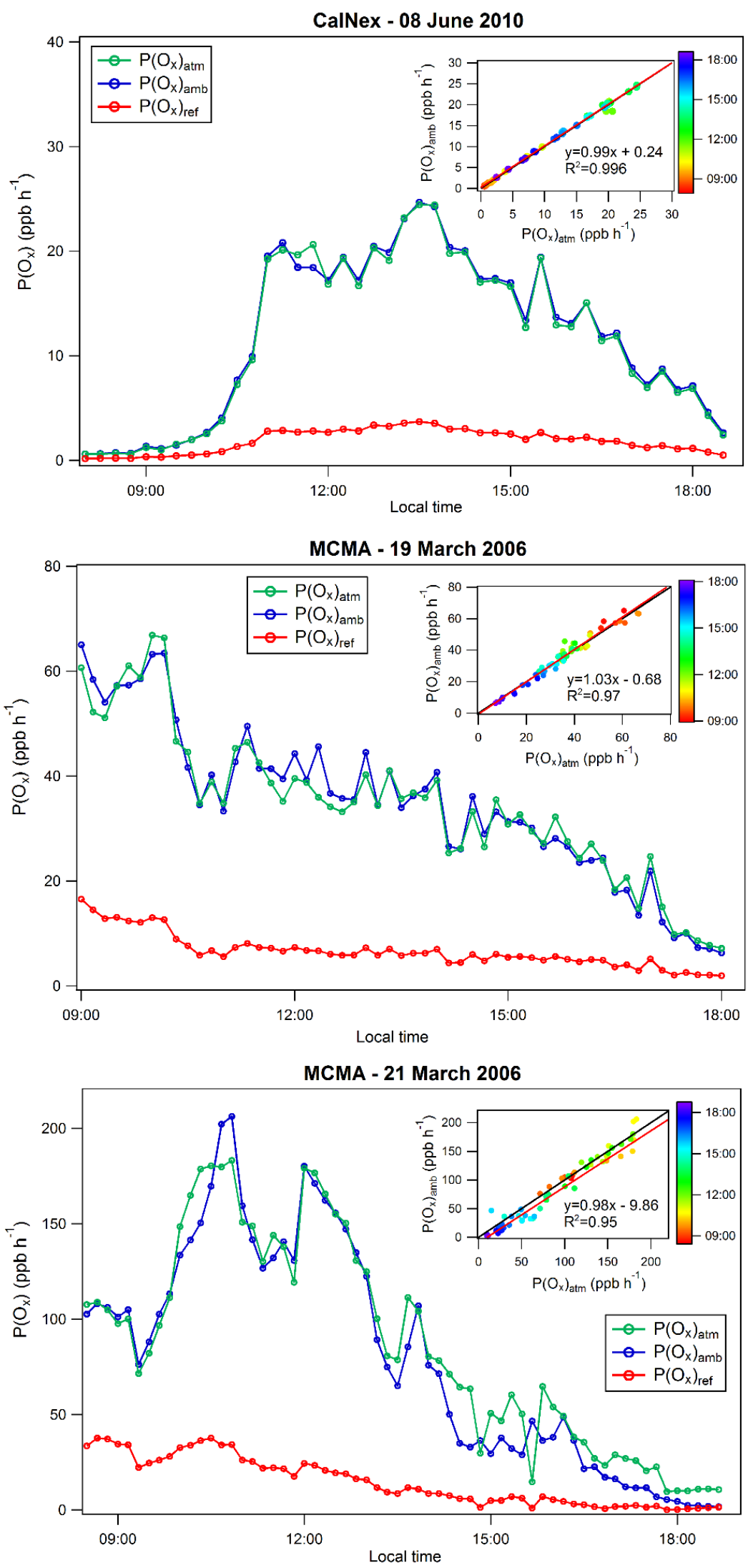

2 Figure S10. Modeled ozone production in the ambient atmosphere, $\mathrm{P}\left(\mathrm{O}_{\mathrm{x}}\right)_{\text {atm }}$, in the ambient flow tube, $\mathrm{P}\left(\mathrm{O}_{\mathrm{x}}\right)_{\text {amb }}$, and in the reference flow tube, $\mathrm{P}\left(\mathrm{O}_{\mathrm{x}}\right)_{\text {ref }}$, on 08 May 2010 of CalNex-2010 (top), on 19 March 2006 of MCMA2006 (middle) and on 21 March 2006 of MCMA-2006 (bottom). Insert plots show the correlation between $\mathrm{P}\left(\mathrm{O}_{\mathrm{x}}\right)_{\mathrm{atm}}$ and $\mathrm{P}\left(\mathrm{O}_{\mathrm{x}}\right)_{\mathrm{amb}}$, color-coded for the time of the day. 

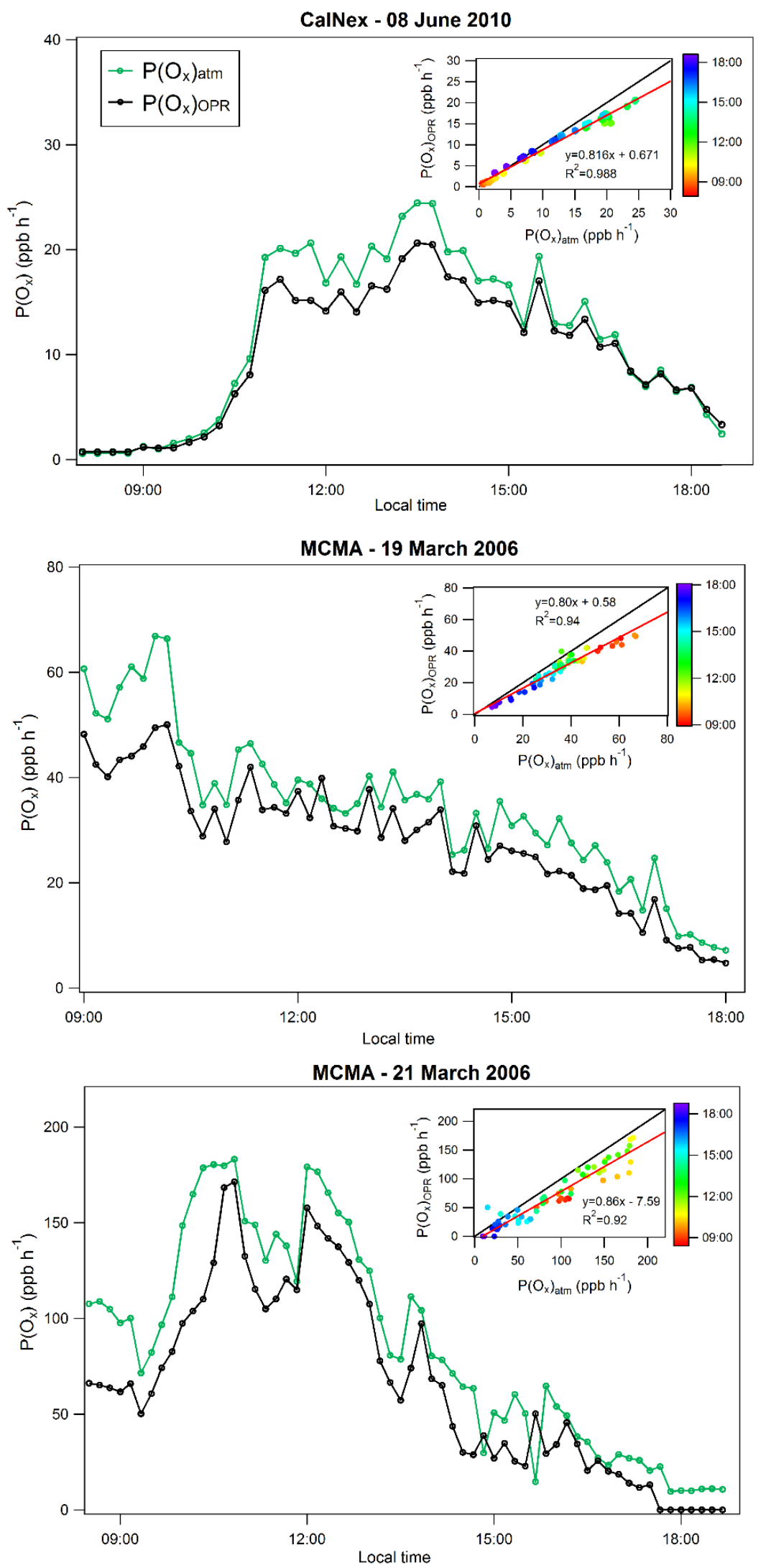

Figure S11. Modeled OPR ozone production, $\mathrm{P}\left(\mathrm{O}_{\mathrm{x}}\right)_{\mathrm{OPR}}$, and modeled ozone production in the ambient atmosphere, $\mathrm{P}\left(\mathrm{O}_{\mathrm{x}}\right)_{\mathrm{atm}}$, on 08 May 2010 of CalNex-2010 (top), on 19 March 2006 of MCMA-2006 (middle) and on 21 March 2006 of MCMA-2006 (bottom). Insert plots show the correlation between $\mathrm{P}\left(\mathrm{O}_{\mathrm{x}}\right)_{\mathrm{atm}}$ and $\mathrm{P}\left(\mathrm{O}_{\mathrm{x}}\right)_{\mathrm{amb}}$, color-coded for the time of the day. 

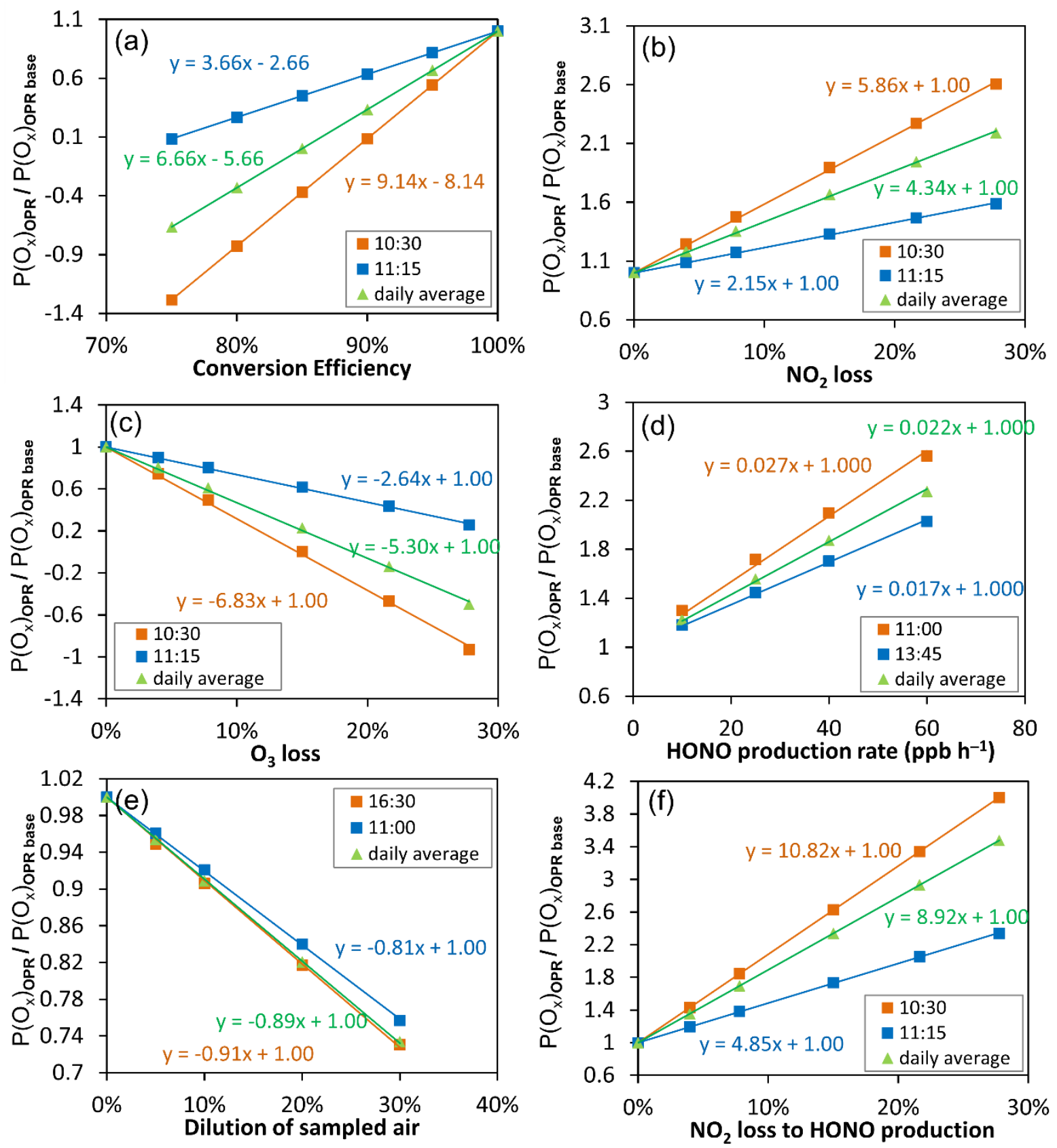

Figure S12. Sensitivity tests performed for 08 June 2010 (CalNex-2010) to assess the impact on $\mathrm{P}\left(\mathrm{O}_{\mathrm{x}}\right)$ measurements of (a) the $\mathrm{O}_{3}$-to- $\mathrm{NO}_{2}$ conversion efficiency, (b) $\mathrm{NO}_{2}$ and (c) $\mathrm{O}_{3}$ dark losses, (d) heterogeneous $\mathrm{HONO}$ formation, (e) dilution of ambient air and (f) $\mathrm{NO}_{2}$ loss towards HONO production in the flow tubes. The results presented here correspond to the two time periods of the day identified as lower and upper limits of the impact on the $\mathrm{P}\left(\mathrm{O}_{\mathrm{x}}\right)$ measurements. The daily average behavior is also shown in green. 

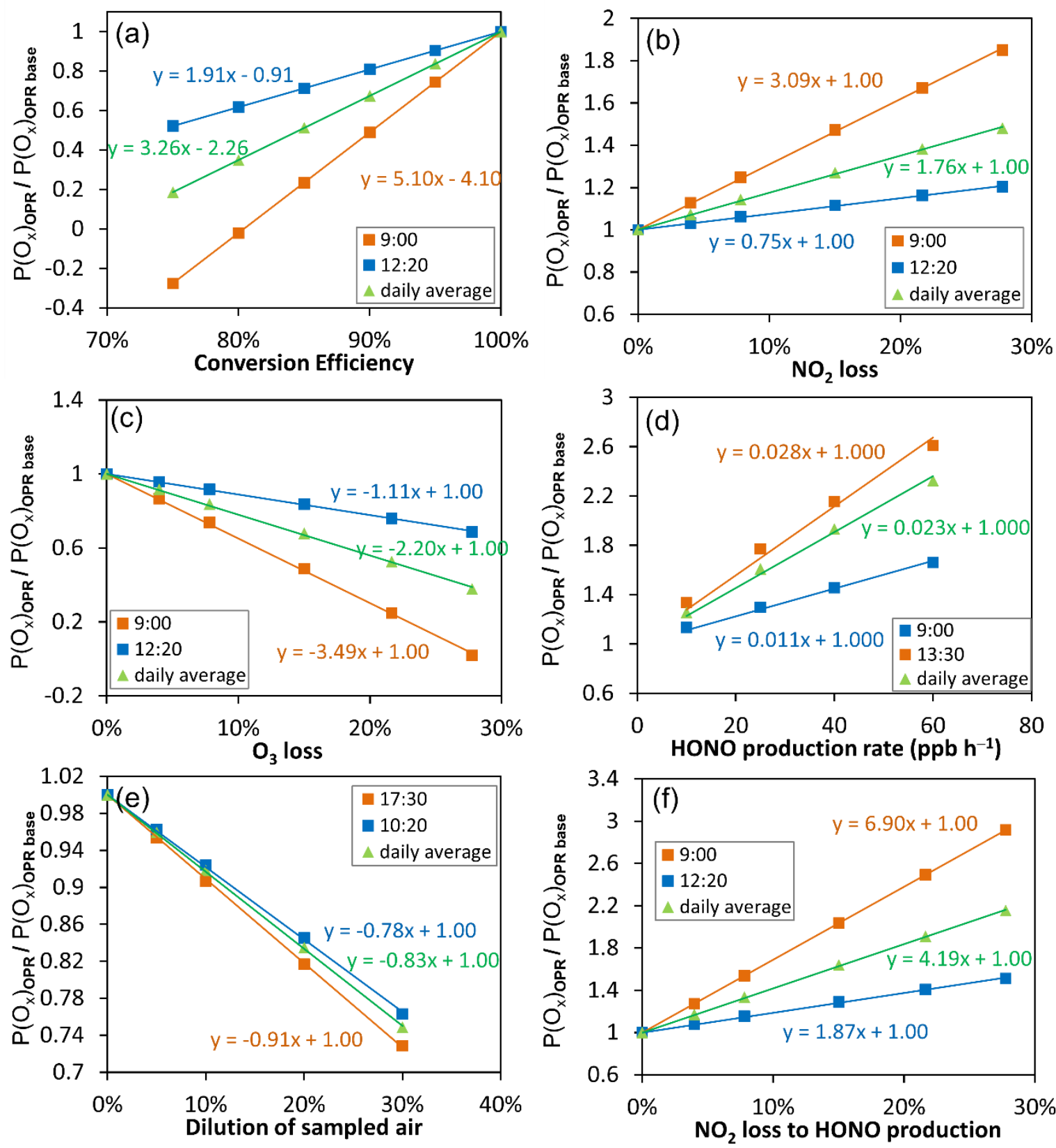

2 3

Figure S13. Sensitivity tests performed for 19 March 2006 (MCMA-2006) to assess the impact on $P\left(\mathrm{O}_{x}\right)$ measurements of (a) the $\mathrm{O}_{3}$-to- $\mathrm{NO}_{2}$ conversion efficiency, (b) $\mathrm{NO}_{2}$ and (c) $\mathrm{O}_{3}$ dark losses, (d) heterogeneous HONO formation, (e) dilution of ambient air and (f) $\mathrm{NO}_{2}$ loss towards HONO production in the flow tubes. The results presented here correspond to the two time periods of the day identified as lower and upper limits of the impact on the $\mathrm{P}\left(\mathrm{O}_{\mathrm{x}}\right)$ measurements. The daily average behavior is also shown in green. 

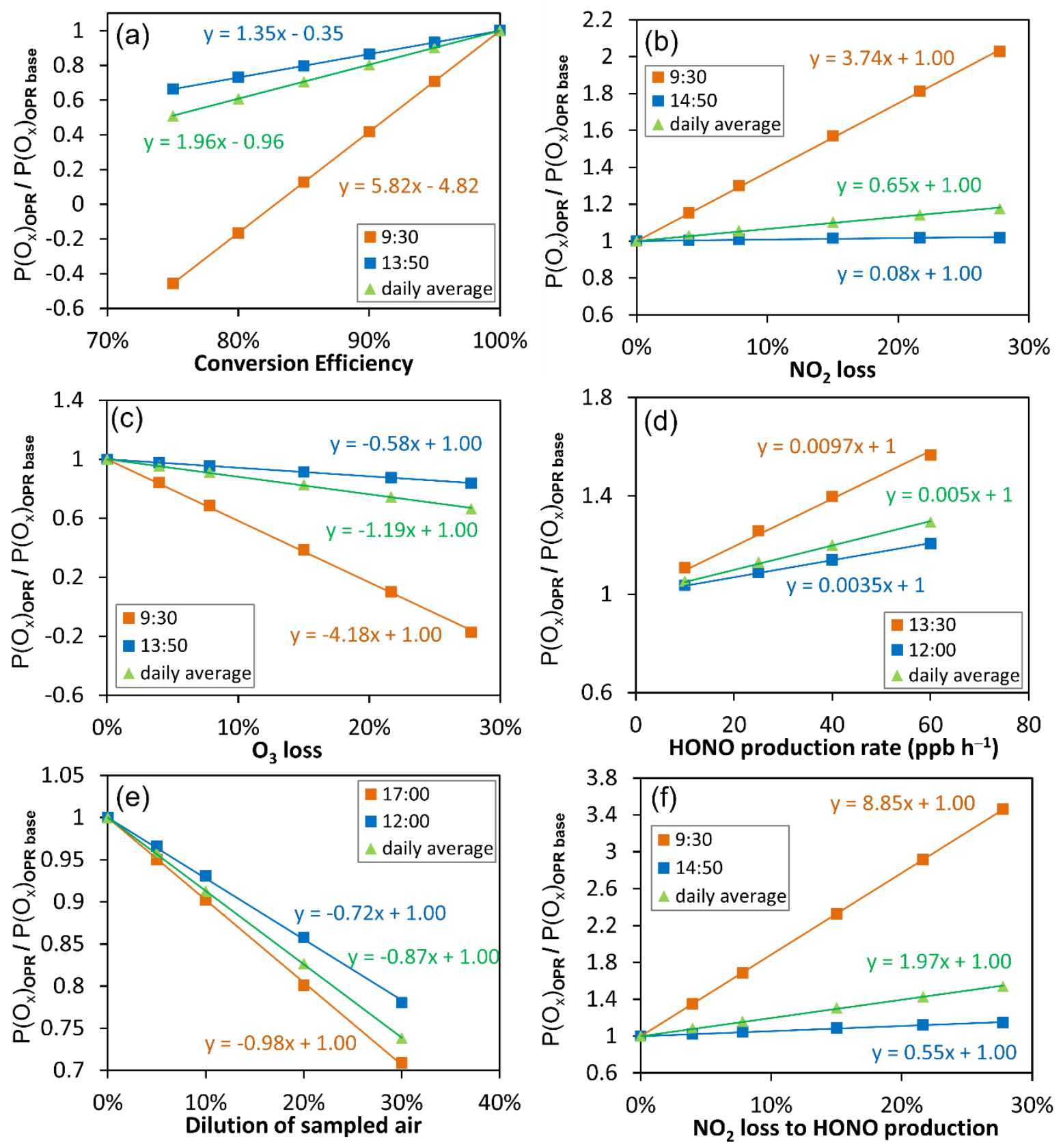

2

Figure S14. Sensitivity tests performed for 21 March 2006 (MCMA-2006) to assess the impact on $P\left(O_{x}\right)$ measurements of (a) the $\mathrm{O}_{3}$-to- $\mathrm{NO}_{2}$ conversion efficiency, (b) $\mathrm{NO}_{2}$ and (c) $\mathrm{O}_{3}$ dark losses, (d) heterogeneous HONO formation, (e) dilution of ambient air and (f) $\mathrm{NO}_{2}$ loss towards $\mathrm{HONO}$ production in the flow tubes. The results presented here correspond to the two time periods of the day identified as lower and upper limits of the impact on the $\mathrm{P}\left(\mathrm{O}_{\mathrm{x}}\right)$ measurements. The daily average behavior is also shown in green. 


\section{References}

3 Madronich, S., and Flocke, S.: The Role of Solar Radiation in Atmospheric Chemistry, in:

4 Environmental Photochemistry, edited by: Boule, P., The Handbook of Environmental Chemistry,

$5 \quad$ Springer Berlin Heidelberg, 1-26, 1999.

6 Philipp, H. R., Le Grand, D. G., Cole, H. S., and Liu, Y. S.: The optical properties of a 7 polyetherimide, Polymer Engineering \& Science, 29, 1574-1578, 1989.

8 Stockwell, W. R., Kirchner, F., Kuhn, M., and Seefeld, S.: A new mechanism for regional 9 atmospheric chemistry modeling, Journal of Geophysical Research: Atmospheres, 102, 25847-25879, 101997. 